\title{
The Incorporation of Indigenous and Local Knowledge into Central Arctic Ocean Fisheries Management
}

\author{
Valentin Schatz ${ }^{\star}$ \\ University of Hamburg
}

On October 3, 2018, the so-called "Arctic Five plus Five"1 concluded the Agreement to Prevent Unregulated High Seas Fisheries in the Central Arctic Ocean (CAOFA, CAOF Agreement or Ilulissat Agreement). ${ }^{2}$ The CAOFA establishes a precautionary framework for the regulation of fisheries in the high seas of the central Arctic Ocean $(\mathrm{CAO})$, including a temporary moratorium on unregulated commercial fishing. ${ }^{3}$ The purpose of this debate article is not to discuss the CAOFA's provisions on fisheries as such, but to take a look at a number of interesting and novel provisions concerning the interests of indigenous and local communities, particularly with respect to incorporation of indigenous and local knowledge into science-based fisheries management in the CAO. ${ }^{4}$

1 The term refers to the five Arctic Ocean coastal States (Canada, Denmark (in respect of Greenland and the Faroe Islands), Norway, Russia, and the United States) and, in addition, China, Iceland, Japan, South Korea and the European Union.

2 Agreement to Prevent Unregulated High Seas Fisheries in the Central Arctic Ocean (Ilulissat, 3 October 2018, not yet in force). For a text of the CAOFA, see European Commission, "Annex to the Proposal for a Council Decision on the Signing, on Behalf of the European Union, of the Agreement to Prevent Unregulated High Seas Fisheries in the Central Arctic Ocean", 12.6.2018, COM(2018) 454 final, https://eur-lex.europa.eu/ legal-content/EN/TXT/PDF/?uri=CELEX:52018PC0453\&from=EN.

3 For commentary on the CAOFA, see Valentin Schatz, Alexander Proelss and Nengye Liu, "The 2018 Agreement to Prevent Unregulated High Seas Fisheries in the Central Arctic Ocean: A Critical Analysis," International fournal of Marine and Coastal Law 34 (2019): https://doi.org/10.1163/15718085-23342015; Andrew Serdy, "The Agreement to Prevent Unregulated High Seas Fisheries in the Central Arctic Ocean: An Overview," Ocean Yearbook 33 (2019): (forthcoming).

4 The CAOFA's coverage of indigenous interests more generally was the subject of the presentation 'The CAOF Agreement and Indigenous Interests' by Nigel Bankes at the 11th

(C) 2019 Valentin Schatz. This is an Open Access article distributed under the terms of the Creative Commons Attribution-NonCommercial 4.0 International License (https://creativecommons.org/licenses/by-nc/4.0/), allowing third parties to share their work (copy, distribute, transmit) and to adapt it, under the condition that the authors are given credit, that the work is not used for commercial purposes, and that in the event of reuse or distribution, the terms of this license are made clear.

Citation:Valentin Schatz. "The Incorporation of Indigenous and Local Knowledge into Central Arctic Ocean Fisheries Management" Arctic Review on Law and Politics, Vol. 10, 2019, pp. 130-134. http://dx.doi.org/10.23865/arctic.v10.1630 
Indigenous peoples' participation and incorporation of traditional knowledge into decision-making are increasingly acknowledged in multilateral environmental treaties and soft-law documents..$^{5}$ In particular, this notion is reflected in Agenda $21^{6}$ and the 2007 United Nations Declaration on the Rights of Indigenous Peoples (UNDRIP). ${ }^{7}$ Indeed, indigenous and local knowledge represents valuable ecosystem information acquired over long periods of time. Various treaties dealing with Arctic issues make reference to indigenous special interests or participation. ${ }^{8}$ The most prominent intergovernmental forum that provides for the active participation of Arctic indigenous peoples is the Arctic Council. ${ }^{9}$ The incorporation of traditional knowledge into Arctic fisheries management also occurs at the national level. The North Pacific Council of the United States, for instance, adopted a Bering Sea Fishery Ecosystem Plan in December 2018, which expressly addresses the necessity to incorporate traditional and local knowledge into its management strategy..$^{10}$ Such indigenous and local knowledge may, for example, be useful for the management of marine fisheries like the anadromous Bering Sea salmon fishery, which is affected by salmon bycatch in the pollock fisheries of the high seas of the Bering Sea. Yet, an analysis of the NAFO Convention ${ }^{11}$ and the NEAFC Convention ${ }^{12}$ - the most important (sub-) Arctic high seas fisheries agreements - demonstrates that provisions

Polar Law Symposium on 2-4 October 2018 at The Arctic University of Norway, Tromsø, Norway.

5 Benedict Kingsbury. "Indigenous Peoples," in Max Planck Encyclopedia of Public International Law, ed. Rüdiger Wolfrum (Oxford: Oxford University Press, 2006), paras. $22 \mathrm{ff}$.

6 Para. 26.3(a)(iii) of the United Nations Conference on Environment \& Development Rio de Janeiro, Agenda 21 (14 June 1992), https://sustainabledevelopment.un.org/content/ documents/Agenda21.pdf.

7 Article 31 of the United Nations General Assembly, United Nations Declaration on the Rights of Indigenous Peoples (13 September 2007), http://www.un.org/esa/socdev/unpfii/ documents/DRIPS_en.pdf.

8 See, e.g., Article 3(1) of the Agreement on the Conservation of Polar Bears (15 November 1973) 2898 UNTS 243.

9 Sebastian Knecht, "The Politics of Arctic International Cooperation: Introducing a Dataset on Stakeholder Participation in Arctic Council Meetings, 1998-2015," Cooperation and Conflict 52 (2017): 219-220; Leena Heinämäki, "Rethinking the Status of Indigenous Peoples in International Environmental Decision-Making: Pondering the Role of Arctic Indigenous Peoples and the Challenge of Climate Change," in Climate Governance in the Arctic, ed. Timo Koivurova, E. Carina H. Keskitalo and Nigel Bankes (Dordrecht: Springer, 2009), 246-252.

10 Para. 6.3.4 of the Draft Bering Sea Fishery Ecosystem Plan (2018), https://www.npfmc.org/ bsfep/.

11 Convention on Future Multilateral Co-operation in the Northwest Atlantic Fisheries: 1135 UNTS 369.

12 Convention on Future Multilateral Cooperation in North-East Atlantic Fisheries: 1285 UNTS 129. 
on science-based fisheries management are present, ${ }^{13}$ but that provisions concerning the incorporation of Arctic indigenous and/or local knowledge have not been included. ${ }^{14}$

It has been proposed that indigenous and local knowledge might contribute to CAO fisheries management given that "especially in the adjacent waters this body of knowledge may offer insights and time depth unavailable from any other sources." 15 This was not, however, immediately acknowledged by the Arctic States. To the disappointment of Arctic indigenous peoples, their representatives were not included in the negotiations leading to the adoption of the 2008 Ilulissat Declaration, ${ }^{16}$ which preceded the CAOFA negotiations. ${ }^{17}$ For this reason, the Inuit Circumpolar Council (ICC) adopted its 2009 Circumpolar Inuit Declaration on Sovereignty in the Arctic (ICC Declaration) ${ }^{18}$ which demanded more Inuit participation, and which expressly highlights the role of indigenous knowledge in Arctic fisheries management. ${ }^{19}$

Thereafter, the ICC adopted its 2014 Kitigaaryuit Declaration, ${ }^{20}$ which called for an "inclusion of Inuit representatives on all councils, committees, and commissions formed to address Arctic fishing issues" ${ }^{21}$ Some Arctic States have reacted to these calls by including representatives from indigenous organizations in their delegations, namely, Canada, ${ }^{22}$ the United States, and Denmark (with respect to Greenland's indigenous population). ${ }^{23}$

13 Article 3(b) NAFO Convention; Article 4(2) (e) NEAFC Convention.

14 So far, no incorporation of indigenous knowledge has been documented by NEAFC. A potential reason for this is that NEAFC predominantly regulates commercial high seas fisheries rather than subsistence-fisheries. See E-Mail correspondence of the author with NEAFC Secretary Dr. Darius Campbell (22 August 2018).

15 Thomas I. Van Pelt et al., "The Missing Middle: Central Arctic Ocean Gaps in Fishery Research and Science Coordination," Marine Policy 85 (2017): 80.

16 Arctic Ocean Conference, Ilulissat Declaration (28 May 2008), http://www.oceanlaw.org/ downloads/arctic/Ilulissat_Declaration.pdf.

17 Kamrul Hossain, "How Great Can a "Greater Say" Be? Exploring the Aspirations of Arctic Indigenous Peoples for a Stronger Engagement in Decision-making," The Polar fournal 3 (2013): 327.

18 ICC, Circumpolar Inuit Declaration on Sovereignty in the Arctic (28 April 2009), http:// inuit.org/about-icc/icc-declarations/sovereignty-declaration-2009/.

19 Paras. 3.4 and 3.5 ICC Declaration.

20 ICC, Kitigaaryuit Declaration (24 July 2014), http://www.inuitcircumpolar.com/uploads/ 3/0/5/4/30542564/img-724172331.pdf.

21 Para. 20 Kitigaaryuit Declaration.

22 The Canadian government confirmed that it "worked with Arctic Indigenous peoples throughout the negotiation process" and that members of the ICC were part of the Canadian delegation. See http://www.dfo-mpo.gc.ca/international/arctic-arctique-eng.htm\#_About_the_ agreement.

23 Erik J. Molenaar, "The December 2015 Washington Meeting on High Seas Fishing in the Central Arctic Ocean,” The fCLOS Blog (2016): 3, http://site.uit.no/jclos/files/2016/04/ 
Probably as a result of the participation of indigenous representatives during the negotiations, the CAOFA contains a number of provisions dealing with indigenous and local communities and their knowledge. The preamble of the CAOFA recalls the UNDRIP, recognizing "the interests of Arctic residents, including Arctic indigenous peoples, in the long-term conservation and sustainable use of living marine resources and in healthy marine ecosystems in the Arctic Ocean", and underlining "the importance of involving them and their communities". ${ }^{24}$ In the last clause of the preamble, the desire "to promote the use of both scientific knowledge and indigenous and local knowledge of the living marine resources of the Arctic Ocean and the ecosystems in which they occur as a basis for fisheries conservation and management in the high seas portion of the central Arctic Ocean" is further expressed. ${ }^{25}$ Thus, despite its special emphasis on the role of indigenous peoples, the preamble recognizes not only the relevance of indigenous knowledge, but also, a more general need to integrate local knowledge and science.

To a certain extent, this recognition is also reflected in the operative part of the CAOFA: Article 4(1) contains a general obligation to "facilitate cooperation in scientific activities with the goal of increasing knowledge of the living marine resources of the central Arctic Ocean and the ecosystems in which they occur." For this purpose, Article 4(2) envisages the establishment of a Joint Program of Scientific Research and Monitoring (JPSRM) with the aim "of improving their understanding of the ecosystems of the Agreement Area and, in particular, of determining whether fish stocks might exist in the Agreement Area now or in the future that could be harvested on a sustainable basis and the possible impacts of such fisheries on the ecosystems of the Agreement Area". ${ }^{26}$ Article 4(4) obliges the parties to "ensure that [the JPSRM] takes into account the work of relevant scientific and technical organizations, bodies and programs, as well as indigenous and local knowledge." Article $5(1)(b)$ requires the parties to "review all available scientific information developed through [the JPSRM], from the national scientific programs, and from any other relevant sources, including indigenous and local knowledge" during their biannual meetings. Crucially, Article 5(1)(c) prescribes that a decision regarding whether or not the CAO will support a commercial fishery, must be based on an integration of scientific knowledge derived from the JPSRM with available indigenous and local knowledge. It is only after such a decision is made that negotiations on the establishment of one or more additional regional fisheries management organizations or arrangements (RFMOs/As) may commence under Article 5(1)(c)(i). In effect, the most fundamental decisions concerning fisheries management under the CAOFA

The-December-2015-Washington-Meeting-on-High-Seas-Fishing-in-the-Central-ArcticOcean.pdf.

24 Preamble of the CAOFA.

25 Preamble of the CAOFA.

26 For discussion of the JPSRM, see Schatz, Proelss and Liu (n 3). 
must also take into account indigenous and local knowledge. One question that remains is how this knowledge should be obtained. Article 5(2) permits the parties to "form committees or similar bodies in which representatives of Arctic communities, including Arctic indigenous peoples, may participate" in order to promote the implementation of the CAOFA, and also with respect to the JPSRM and related activities. However, the parties are not obliged to do so, which means that the decision to enable participation by Arctic communities is entirely left to the discretion of the parties. Arguably, however, if a party chooses to establish such a body, it must not exclude the Arctic communities from participation in this body. Overall, it may be held that the CAOFA contains a clear obligation to incorporate indigenous and local knowledge once it has been gathered, but contains only weak provisions with respect to the gathering of such knowledge in the first place.

Based on this analysis, it cannot be held that the demands of Arctic indigenous peoples as formulated in the ICC Declaration and the Kitigaaryuit Declaration have been fully met. Time will tell whether the incorporation of indigenous and local knowledge into CAOFA's machinery will have a noticeable impact on CAO fisheries management. For now, it appears that such incorporation may prove difficult. Participants of the Fifth Meeting of Scientific Experts on Fish Stocks in the Central Arctic Ocean (FiSCAO), which was part of a series of meetings of scientific experts parallel to -and in support of- the negotiations on the CAOFA "recognized that Indigenous and Local Knowledge is an important source of information, but also noted that invited experts and Indigenous and Local Knowledge holders were not available to participate in the meeting [and] invited the ICC to submit comments that may be appended to the full meeting report if ICC so chooses" ${ }^{27}$ Nonetheless, the ICC's 2018 Utqiagivik Declaration emphasized that indigenous knowledge should be utilized "to advise all future processes of the Central Arctic Ocean Moratorium on Commercial Fisheries". ${ }^{28}$ Until this happens, the incorporation of indigenous and local knowledge in the CAOFA remains a symbolic victory for indigenous and local communities affected by the effects of climate change on the Arctic marine ecosystem.

27 Chair's Statement, 5th Meeting of Scientific Experts on Fish Stocks of the Central Arctic Ocean (Ottawa, 24-26 October 2017) https://www.afsc.noaa.gov/Arctic_fish_stocks_fifth_ meeting/pdfs/5th_FiSCAO_chair_statement_final.pdf, 2.

28 ICC, Utqiagivik Declaration (16-19 July 2018) https://www.arctictoday.com/wp-content/uploads/2018/07/2018-Utigavik-Declaration.pdf. 